\title{
Selvmord ved depresjon med psykotiske symptomer og bipolar lidelse: forekomst, risikofaktorer og nevrobiologiske forhold
}

\author{
Ved Erlend Mork, Lars Mehlum og Fredrik A. Walby
}

\begin{abstract}
Formålet med denne artikkelen er først å beskrive kliniske og demografiske forhold som kan bidra til vår forståelse av den sterkt forhøyede risikoen for død ved selvmord hos pasienter med depresjon med psykotiske symptomer og ved bipolar lidelse. Dernest vil vi beskrive nevrobiologiske forhold og genetiske faktorer knyttet til de nevnte lidelsene.
\end{abstract}

En eller flere psykisk lidelser er i tallrike studier funnet å være til stede ved mer enn $90 \%$ av alle gjennomførte selvmord (Cavanagh et al., 2003). Psykisk lidelse er således den risikofaktoren som er sterkest assosiert med selvmord. Estimater av livstidsrisikoen for selvmord ved affektive lidelser (inkludert bipolar lidelse og depresjon) på opptil $15 \%$ har lenge versert i læreb $\varnothing$ ker og i fagmiljøet (Inskip et al., 1998). Nyere metaanalyser har imidlertid benyttet bredere utvalg og mer presise statistiske metoder, og estimerer livstidsrisikoen for $\mathrm{d} \varnothing \mathrm{d}$ ved selvmord til rundt $6 \%$ for affektive lidelser (Inskip et al., 1998). Selv med dette mer konservative anslaget er risikoen for selvmord hos pasienter med affektiv lidelse 10-20 ganger høyere enn i befolkningen generelt, avhengig av utvalget man studerer (Harris \& Barraclough, 1997). Det er også en overhyppighet av selvmordsfors $\varnothing \mathrm{k}$ blant personer med affektive lidelser, hvor livstidsforekomsten er anslått fra 20-50 \% (Jamison, 2000; Goodwin \& Jamison, 1990; Haw et al., 2005). Risikoen for død ved selvmord er ved psykoselidelser særlig forhøyet tidlig i sykdomsforløpet (Palmer et al., 2005) og i forbindelse med sykehusinnleggelser, både under innleggelse og i tiden etter utskrivning (Qin \& Nordentoft, 2005).

$\AA$ predikere hvem som vil gjennomføre et selvmord er i utgangspunktet svært vanskelig, dels fordi selvmord er et relativt sjeldent fenomen og dels fordi kjente risikofaktorer har lav sensitivitet og spesifisitet. Allikevel er kunnskap om sentrale risikofaktorer for selvmord en viktig st $\varnothing t t e$ for behandlere i de krevende og avgjørende kliniske avveiningene en må gjøre i møte med selvmordstruede pasienter.

\section{Depresjon med psykotiske symptomer}

Depresjon som risikofaktor er særlig viktig av flere grunner: Depressive symptomer er nært knyttet til suicidal atferd direkte gjennom depressive episoder, dessuten sees depressive symptomer også ofte ved andre lidelser. Depressive lidelser er svært vanlige. Livstidsprevalensen er i Norge ca. $18 \%$ for markert depresjon (Major Depression) og ca. $10 \%$ for dystymi (Kringlen et al., 2001). Både DSM-IV og ICD-10 opererer med tre alvorlighetsgrader for markert depresjon; mild, moderat og alvorlig. Sistnevnte deles videre inn i alvorlig depresjon med og uten psykotiske symptomer.

En depressiv psykose er karakterisert ved forekomst av hallusinasjoner eller vrangforestillinger i tillegg til depressive symptomer. Mest vanlig er vrangforestillinger, og disse har som regel et stemningskongruent preg. Det vil si at pasienten har virkelighetsbristende idéer om skyld, skam, sykdom, forfølgelse, å ha begått feil og lignende. Det er ikke uvanlig at pasienten på psykotisk grunnlag opplever døden som det beste alternativet for en selv og eventuelt også for andre. Derfor kan slike tilstander også føre til drap. (Walby, 2004)

Om lag 4 av 1000 personer i den generelle befolkningen vil til enhver tid ha en depressiv psykose. Tilsvarende har ca. 15-19\% av personer med markert depresjon også psykotiske symptomer (Wijkstra et al., 2005). For pasienter som har vært behandlet på sykehus for depresjon, vil antallet med psykotiske symptomer være høyere. Sammenliknet med ikke-psykotisk depresjon er psykotisk depresjon oftest mer alvorlig, pasientens funksjonsnivå lavere, episodene varer lengre, tilbakefallsraten er høyere og psykotiske symptomer kommer gjerne tilbake i senere sykdomsepisoder (Wijkstra et al., 2005). Det ser også ut til å være forskjeller i spesifikke depresjonssymptomer; studier har konsistent funnet mer psykomotorisk agitasjon eller retardasjon og $\varnothing \mathrm{kt}$ skyldf $\varnothing$ lelse blant psykotisk deprimerte (Keller et al., 2007).

Det er hevet over tvil at pasienter med depresjon er en høyrisikogruppe med tanke på selvmord. Klinisk er det vanlig å anse selvmordsfaren som særlig sterk ved depresjoner med psykotiske symptomer, men dette er overaskende nok lite studert. En studie (Roose et al., 1983) har blant annet funnet at slike symptomer $\varnothing$ ker risikoen for selvmord mer enn 5 ganger sammenliknet med depresjon uten psykose. Derimot har andre (Black et al., 1988) ikke funnet forskjell i suicidrate mellom psykotisk og ikke-psykotisk deprimerte pasienter. Klinisk ser man ofte at psykotiske symptomer kan komme eller forsvinne meget raskt ved depresjon, og de er således vanskelige å fange opp både i prospektive og retrospektive studier av gjennomf $\varnothing$ rte selvmord. Som ved andre former for psykose vil ofte ikke de psykotiske symptomene rapporteres spontant av pasienten, til dels vil man også kunne fors $\varnothing$ ke å skjule disse. Det er derfor grunn til å tro at betydningen av psykotiske symptomer blir underestimert både i forskning og klinikk. Begge studiene som er referert over, er relativt gamle.

I en nyere norsk studie av alle selvmord hos pasienter som hadde vært innlagt til behandling i psykisk helsevern i Oslo mindre enn tre år f $\varnothing$ r selvmordet, fant man at depresjon var den sterkeste risikofaktoren for selvmord sammenliknet med alle andre diagnoser (Walby et al., 2006). Depressive tilstander $\varnothing$ kte risikoen med om lag tre ganger uavhengig av betydningen av andre faktorer. Dette materialet var for lite til at man kunne studere betydningen av undergrupper av depresjon. Man fant allikevel en klar trend for $\varnothing \mathrm{kt}$ risiko med $\varnothing$ kende alvorsgrad og for depressiv psykose. $\varnothing \mathrm{kt}$ risiko med $\varnothing$ kende alvorlighetsgrad av depresjon er også funnet i to store registerstudier (Kessing, 2004; Simon \& VonKorff, 1998) uten at depressiv psykose utgjorde en egen undergruppe i analysene. Generelt er det en stor mangel på studier av omfanget av og risikofaktorer for selvmord ved depressive psykoser.

\section{Bipolar lidelse}

Bipolar lidelse er karakterisert ved episoder med depressive og maniske (bipolar I) eller hypomane (bipolar II) episoder 


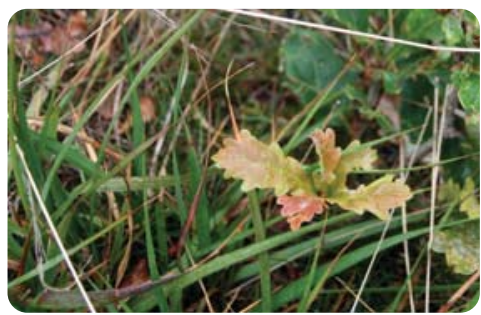

gjennom livsløpet. Psykotiske symptomer kan være en del av det kliniske bildet både i depressiv og manisk fase. I tillegg har noen pasienter et klinisk bilde preget av raske svingninger i stemningsleiet (rapid cycling). Konservative anslag av livstidsforekomsten av bipolar lidelse i befolkningen er estimert til 0,5-1\% for bipolar I og til 1,5-2 \% for bipolar I og II totalt (Merikangas et al., 2007; Pini et al., 2005). En psykologisk autopsistudie (Isometsa et al., 1994) peker mot at selvmord ved bipolar lidelse oftest skjer i den depressive fasen av lidelsen, men også ved 'mixed state' (blandet tilstand; perioder hvor lidelsen karakteriseres av både symptomer på oppstemthet/mani og symptomer på depresjon innenfor et kort tidsrom) eller mer sjeldent, ved mani med psykotisk symptomer. Ved 1/3 av suicidene i ovennevnte studie hadde pasienten hatt psykotiske symptomer ved siste affektive episode. Forskerne fant også at pasientene ofte ikke hadde fått adekvat behandling eller de hadde ikke fulgt opp behandlingen. Pasientene med bipolar lidelse som døde ved selvmord, hadde ofte høy grad av komorbide lidelser. Kanskje er komorbid angstlidelse av særlig betydning. En nyere populasjonsbasert unders $\varnothing$ kelse av personer behandlet for bipolar lidelse viste at komorbid angstlidelse var forbundet med signifikant $\varnothing \mathrm{kt}$ risiko for både selvmordsfors $\varnothing \mathrm{k}$ og for d $\varnothing \mathrm{d}$ ved selvmord

(Simon et al., 2007).

En systematisk oversikt fra 2005 over $\mathrm{d} \varnothing \mathrm{d}$ ved selvmord blant pasienter med bipolar lidelse viser at tidligere selvmordsfors $\varnothing \mathrm{k}$ samt håpløshet på unders $\varnothing$ kelsestidspunktet er sterkt forbundet med $\varnothing \mathrm{kt}$ selvmordsrisiko (Hawton et al., 2005). Menn med en bipolar lidelse har signifikant høyere risiko for $\mathrm{d} \varnothing \mathrm{d}$ ved selvmord enn kvinner. Dette er funn som er i tråd med hva vi vet om risikoen i befolkningen for $\varnothing$ vrig. Det er imidlertid verd å merke seg at det ikke er funnet en systematisk sammenheng mellom bipolar lidelse og selvmord når det gjelder andre sosiodemografiske forhold (f.eks. tilknytning til arbeidslivet, sivilstatus). Heller ikke tidlige tapsopplevelser, sosial isolasjon eller tilsvarende personlige eller sosiale faktorer er funnet å $\varnothing$ ke eller redusere risikoen systematisk for selvmord i denne pasientgruppen. Da dette er risikofaktorer eller beskyttende faktorer i befolkningen generelt, er det verdt å merke seg dette. Det er imidlertid få gode studier om risikofaktorer for selvmord ved bipolar lidelse, og det er derfor en klar mulighet for at noen risikofaktorer for selvmord ikke fanges opp.

Et sekundært alternativ er da å studere risikoen for selvmordsfors $\varnothing \mathrm{k}$, i og med at dette er en robust risikofaktor for $\mathrm{d} \varnothing \mathrm{d}$ ved selvmord. Selvmord og selvmordsfors $\varnothing \mathrm{k}$ har bare delvis overlappende risikofaktorer, og de følgende funns relevans for selvmord må tolkes med forsiktighet. I en systematisk gjennomgang av studier av risikofaktorer for selvmordsfors $\varnothing \mathrm{k}$ ved bipolar lidelse fant man at personer som lever alene og personer som har opplevd selvmord i familien har $\varnothing \mathrm{kt}$ risiko for selvmordsfors $\varnothing \mathrm{k}$ (Hawton et al., 2005). Selv om det så langt ikke er vist en sammenheng mellom fysisk eller seksuell mishandling i oppveksten og selvmord, har en stor studie vist at fysisk eller seksuelt misbruk i oppveksten $\varnothing$ ker risikoen for selvmordsfors $\varnothing \mathrm{k}$ blant pasienter med bipolar lidelse (Leverich et al., 2003). Ung alder ved debut av bipolar lidelse og sykehusinnleggelser i depressiv fase eller ved "mixed state" er forbundet med høyere risiko for selvmordsfors $\varnothing \mathrm{k}$ (Hawton et al., 2005).

$\varnothing \mathrm{kt}$ risiko for selvmordsfors $\varnothing \mathrm{k}$ ser også ut til å være forbundet med tilstander hvor personen opplever en gradvis forverring av både depressive og maniske episoder i forløpet av lidelsen (Leverich et al., 2003). Den systematiske gjennomgangen til Hawton og kollegene (2005) viste også at pasienter med raske svingninger i stemningsleiet (minst 4 avgrensede affektive episoder i løpet av 1 år) har høyere risiko for selvmordsfors $\varnothing \mathrm{k}$ sammenlignet med de to andre diagnostiske hovedgruppene. Som i befolkningen generelt er stoff- og alkoholmisbruk/-avhengighet forbundet med $\varnothing \mathrm{kt}$ forekomst av selvmordsfors $\varnothing \mathrm{k}$ ved bipolar lidelse.

Mange studier i ulike pasientpopulasjoner viser en $\varnothing \mathrm{kt}$ risiko for suicidal atferd relatert til svikt i evnen til å hente fram igjen spesifikke minner. Dette er igjen relatert til sviktende problemløsningsevne og inngår som et viktig element i "Cry of Pain"-modellen for suicidal atferd (Williams, 2001). I en hovedoppgave i psykologi er det nylig vist at slik over- generell autobiografisk hukommelse er assosiert med selvmordsatferd ved schizofreni (Pettersen \& Rydningen, 2006).

Ved en tilsvarende unders $\varnothing$ kelse ved bipolar lidelse (Sanden, 2008) ble det ikke funnet signifikante tendenser i samme retning.

\section{Implikasjoner for praksis}

Denne gjennomgangen viser at det $\mathrm{i}$ klinisk selvmordsforebygging er viktig å behandle depressive episoder og særlig symptomer som håpløshet og selvmordstanker for å redusere tiden pasienten er eksponert for disse symptomene. Rask intervensjon og årvåkenhet i kritiske faser som ved utskrivning fra sykehus og ved gradvis eller brå forverring av den psykotiske lidelsen er også viktig for å forebygge selvmord blant personer med depresjon med psykotiske symptomer og bipolar lidelse. Med framveksten av nye metoder har forskere de siste tiårene $\mathrm{i}$ $\varnothing$ kende grad også studert hvordan nevrobiologiske forhold kan $\varnothing$ ke vår forståelse av suicidal atferd ved depresjon med psykotiske symptomer og bipolar lidelse.

\section{Nevrobiologiske forhold}

\section{Nevrokjemiske faktorer}

Som ved andre psykoselidelser er det store mangler i vår innsikt i årsaksforhold og patofysiologi ved depresjon med psykotiske symptomer og bipolar lidelse. Det samme kan sies om suicidalitet knyttet til disse lidelsene. Som ved studiet av suicidalitet ved andre psykiske lidelser har forskning på mulige biologiske årsaksforhold til suicidal atferd ved de aktuelle lidelser fokusert mye på målbare biologiske korrelater til kliniske kjennetegn ved suicidale individer og suicidal atferd. Man har særlig konsentrert oppmerksomheten om kognitive og emosjonelle variabler som impulsivitet, aggresjon, pessimisme og håpløshet.

Hittil har mye av forskningen tydet på at ved suicidalitet går forstyrrede nevrokjemiske funksjoner på tvers av diagnoser. Det vi skal diskutere i det følgende har derfor gyldighet også i st $\varnothing$ rre grupper enn dem som har depresjon med psykotiske symptomer eller bipolar lidelse. Diagnosespesifikk kunnskap på dette området er altså en mangelvare, men kan skyldes at biologien her ikke nødvendigvis f $\varnothing$ lger våre diagnostiske skillelinjer. 


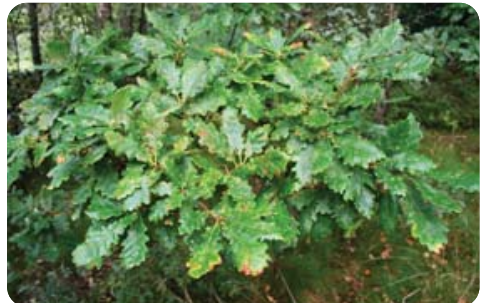

\section{Serotonin}

Serotonin er en av hjernens viktigste signalsubstanser som er involvert i reguleringen av sentrale emosjonelle (angst, stemning, aggresjon) og kognitive funksjoner (impulsivitet). At suicidalitet kan henge sammen med en forstyrret funksjon i serotonerge hjernesystemer, ble påvist av Åsberg og medarbeidere (1976) som fant unormalt lave konsentrasjoner av 5 hydroxy-indol-eddiksyre (5-HIAA) målt i spinalvæsken (CSF - cerebro spinal fluid) hos pasienter som hadde gjort alvorlige selvmordsfors $\varnothing$ k. 5-HIAA er det viktigste nedbrytningsproduktet i hjernens omsetning av serotonin (5-HT). Sammenhengen mellom lave nivåer av CSF 5-HIAA og en forstyrret regulering av aggresjon er påvist både i grupper av suicidale personer og hos individer som har vist betydelig tendens til voldelig atferd (Linnoila et al., 1983). Studier har vist at forstyrrelsene i CSF 5-HIAA ikke er knyttet til sykdomsfase, men er vedvarende - altså at det dreier seg om et biologisk trekk eller hva vi kunne kalle en mark $\varnothing \mathrm{r}$ (Mann \& Arango, 2001). Etter hvert som man har funnet holdepunkter for at denne mark $\varnothing$ ren, lav CSF 5-HIAA, medf $\varnothing$ rer $\varnothing \mathrm{kt}$ risiko for fremtidig suicidal atferd, har man også festet stadig større forhåpninger til at disse nye kunnskapene kan få klinisk nytteverdi. Blant annet har Nordström et al (1994) vist at selvmordsfors $\varnothing$ kere som hadde lave CSF 5HIAA-verdier ved tidspunktet for innleggelse hadde en $\varnothing \mathrm{kt}$ risiko for gjentatte selvmordsfors $\varnothing \mathrm{k}$ året etter utskrivning. Jo lavere CSF 5-HIAA er, desto mer letal viser den suicidale atferden seg å være i unders $\varnothing$ kte pasientgrupper (Mann \& Arango, 2001). Disse sammenhengene innebærer muligheter for at vi i fremtiden kan oppnå større effektivitet $i$ vurderingen av selvmordsrisiko i forhold til dagens situasjon hvor vi sliter med balansen mellom sensitivitet og spesifisitet (Mann et al., 2005).

Det er ikke bare nedbrytningen av serotonin som er forstyrret hos mange pasienter med aggressive og suicidale impulser. Også ved de postsynaptiske serotoninreseptorene har man funnet forstyrrelser, særlig i de såkalte 5-HT1A og 5-HT2A reseptorene (Mann et al., 2003; Rao et al., 1998) der en $\varnothing \mathrm{kt}$ binding av serotonin er funnet i frontallappscortex ved post- mortemstudier av personer som har tatt sitt eget liv.

De fleste av de funn som er gjort i studier av serotoninets rolle ved suicidal atferd, tyder på at det dreier seg om en svikt i den serotonerge signaltransmisjonen $\mathrm{i}$ den prefrontale cortex, og denne svikten utløser en rekke homeostatiske kompensatoriske endringer (Mann \& Currier, 2007), som da er det vi observerer ved våre målinger. Den medfører også en svikt i impuls- og aggresjonsinhibisjonsfunksjoner, som antas å ha stor betydning for risikoen for suicidal atferd på tvers av psykiske lidelser.

Gjennomgangen av serotoninets rolle ved suicidalitet har gyldighet for alle typer depresjon og ikke bare depressive psykoselidelser. Hvilke forhold som gjør seg gjeldende spesifikt ved psykoselidelsene i forhold til suicidalitet, har forskningslitteraturen hittil sagt lite om.

\section{Andre nevrotransmittorer involvert ved suicidal atferd}

Noradrenalin har lenge vært antatt å spille en viktig rolle for utvikling av bipolar lidelse. Svært enkelt uttrykt kan man kanskje si at фkt nivå av noradrenalin kan se ut til å $\varnothing$ ke risikoen for mani, og for lave nivå medfører risiko for depresjon. Samtidig er det funnet holdepunkter for at en ubalanse mellom noradrenerge og serotonerge transmittorssystemer har betydning ved bipolar lidelse og suicidalitet (Wiste et al., 2008). Det er påvist forstyrrelser i hjernens dopaminerge systemer ved depresjon, men det er gjort få studier av hvilken betydning dette har i forhold til suicidalitet. I en prospektiv oppfølgingsstudie fant man hos pasienter med bipolar lidelse en invers sammenheng mellom letalitet av selvmordsfors $\varnothing \mathrm{k}$ i oppfølgingstiden og nivåer av 5-HIAA, HVA og MHPG i spinalvæsken (Sher et al., 2006). De to sistnevnte substansene er metabolitter av henholdsvis dopamin og noradrenalin. Altså var alle de tre viktigste transmittorsystemene i hjernen her involvert, noe som ikke er overraskende, men som uten tvil $\varnothing$ ker kompleksiteten.

\section{Stresshormoner - HPA-aksen}

Den såkalte hypothalamus hypofyse adreno-kortikale akse - HPA-aksen - regulerer kroppens respons på stress og har komplekse interaksjoner med hjernens serotonerge, noradrenerge og dopaminerge systemer. Noen studier (Mann \& Currier, 2007; Plotsky et al., 1998) kan tyde på at hyperaktivitet i HPA-aksen kan være assosiert med suicidalitet. Suicidalitet skulle derfor delvis kunne forklares som en abnormal fysiologisk stressrespons. Et stort antall kliniske studier viser jo en klar sammenheng mellom belastende livshendelser og suicidal atferd (for en oversikt se for eksempel Ferrada-Noli et al., 1998; Mazza \& Reynolds, 1999; Ystgaard et al., 2004). Det er også en erfaring at jo sterkere belastninger og jo flere områder av livet som er ber $\varnothing \mathbf{r t}$ av belastningene og jo lengre belastningen(e) har virket, desto større er risikoen for utvikling av suicidal atferd. Også depresjonstilstander utl $\varnothing$ ses ofte av stressbelastning eller belastende livshendelser, og ved depresjon ser vi ofte aktivering av HPAaksen. Dette har vært observert blant annet gjennom den såkalte dexamethason-suppresjonstesten (Black et al., 2002). I denne testen gir man corticosteroidet dexamethason og måler deretter cortisol i blodet som under normale forhold skal synke, men ved positiv test ikke synker som tegn på at HPA-aksen er aktivert. Også andre tester vil da kunne vise en aktivert HPA-akse, slik som TRH-test eller ACTH-test (Plotsky et al., 1998). Det ser ut til å være en sammenheng mellom det forh $\varnothing y e d e$ cortisolspeilet i blodbanen under vedvarende stress og de tidligere nevnte forstyrrelsene i 5-HTreseptorfunksjonen. I laboratoriefors $\varnothing \mathrm{k}$ på rotter er det vist at kronisk uforutsigbart stress medf $\varnothing$ rer høye serumcortisolnivåer og endringer i 5-HT-reseptorfunksjonene (Lopez et al., 1997). Dersom man på den annen side gir fors $\varnothing$ ksdyret antidepressiva over tid, forhindres flere av forstyrrelsene i 5-HT-reseptorfunksjonen, og dessuten reverseres overaktiviteten i HPA-aksen. Selv om dette foreløpig bare er laboratoriefunn, gir det oss visse holdepunkter for forståelsen av det biologiske substratet for sammenhengen mellom stressbelastning, sviktende affektkontroll og utvikling av suicidal atferd. Mange studier har vist en klar sammenheng mellom tidlig fysisk og seksuell traumatisering og risiko for suicidal atferd (Ystgaard et al., 2004). 


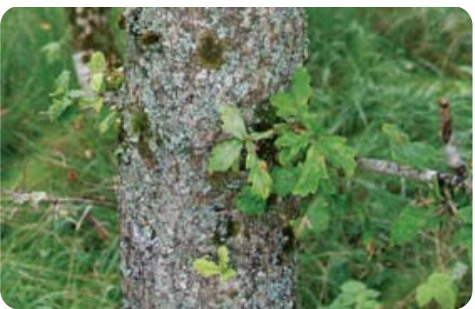

Denne risikoen er sannsynligvis mediert gjennom varige endringer i hjernens stressresponssystemer, noe som er vist gjennom studier av hjernens utvikling hos barn (Glaser, 2000). Også voksne pasienter med bipolar lidelse som har vært eksponert for tidlige fysiske eller seksuelle overgrep, har $\varnothing \mathrm{kt}$ risiko for suicidal atferd (Leverich et al., 2002).

\section{Genetiske faktorer}

Som ved psykoselidelser er det solid evidens for en arvelig komponent ved suicidalitet. Gjennom tvillingstudier (Roy et al., 1991; Fu et al., 2002), adopsjonstudier (Wender et al., 1986), familiestudier (Brent \& Mann, 2005) og molekylærgenetiske studier (Courtet et al., 2005) har man påvist at denne selvmordsrisikoen også er spesifikk og ikke bare arves gjennom psykiske lidelser. Samtidig er det klart at det dreier seg om polygen arv, dvs. at arveligheten knytter seg til flere gener i et komplekst samspill. Når man har lett etter aktuelle gener - såkalte kandidatgener har det vært nærliggende å studere gener som er involvert i serotonerge, noradrenerge eller dopaminerge systemer i hjernen. Også når det gjelder genetikken har det vært serotoninet som har stått mest i fokus for forskningsinnsatsen. I studier av gener som er involvert i serotonin-omsetningen og den serotonerge transmisjon, har man funnet såkalte polymorfismer (varianter av gener som kan medf $\varnothing$ re forstyrret genekspresjon) i serotonin-transportergenet (5-HTTLPR), i gener for reseptorene 5-HT2A, 5-HT1A og 5-HT1B og for tryptofan hydroksylase (TPH) (Courtet et al., 2005) som har sterk påvirkning på produksjonsraten av serotonin, for en oversikt se Carballo et al. (2008). Det er et svært ressurskrevende puslespill å finne fram til hvilke eksakte genetiske endringer som er involvert i forstyrrelser av de ulike nevrotransmittorenes produksjon, funksjon (signaloverføring) og nedbrytning siden det er mange gener involvert og hvert gen i sin tur kan ha tallrike små polymorfismer, såkalte single nukleotid polymorfismer - SNP. Enzymet Monoaminoksidase A (MAOA) er involvert $\mathrm{i}$ metabolismen av både serotonin og noradrenalin. Genet som koder for dette enzymet er plassert på X-kromosomet, og en polymorfisme i dette genet som medfører $\varnothing \mathrm{kt}$ aggressivitet og impulsivitet, kunne bidra til å forklare den betydelige høyere forekomsten av selvmord hos menn i de fleste folkeslag. Et annet enzym involvert i metabolismen av noradrenalin er katekol-o-metyltransferase (COMT). Studier har vist at en Val58Met-polymorfisme i genet som koder for dette enzymet er assosiert med suicidal atferd med bruk av voldsomme metoder hos menn med schizofreni (Nolan et al., 2000).

Som vi beskrev ovenfor, er det mulig å påvise endringer i nevrobiologiske forhold i hjernen etter tidlig og/eller langvarige traumatiske belastninger som $\varnothing$ ker risikoen for suicidal atferd. Genetiske studier har kunnet bekrefte en arv- og miljøinteraksjon. Særlig kjent er den prospektive studien av den såkalte Dunedinkohorten i New Zealand, der om lag 1000 barn ble fulgt fra fødselen med regelmessige unders $\varnothing$ kelser gjennom to tiår. Man kunne her påvise at individer som hadde vært utsatt for fysiske overgrep som barn og som hadde en polymorfisme i 5 -

HTTLPR-genet, hadde signifikant høyere risiko for suicidal atferd enn dem som ikke hadde slik polymorfisme (Caspi et al., 2003). Som vi har sett går de fleste funn i studier som hittil har vært gjort av nevrokjemiske og genetiske faktorer knyttet til suicidalitet, på forhold som ikke er knyttet til spesifikke diagnoser, men til regulering av affekter, kognisjoner og atferd på tvers av diagnoser. Særlig har man kunnet påvise at reguleringen av impulsiv-aggressiv atferd er en sentral faktor. Denne reguleringssvikten kan forklares av både genetiske og miljømessige faktorer, og ikke minst av samspillet mellom arv og miljø.

I denne artikkelen har vi beskrevet demografiske, kliniske og biologiske forhold som kan bidra til vår forståelse av den sterkt forhøyede risikoen for $\mathrm{d} \varnothing \mathrm{d}$ ved selvmord hos pasienter med depresjon med psykotiske symptomer eller bipolar lidelse. Selv om kunnskapen på dette feltet stadig $\varnothing$ ker, er det liten tvil om at det er mye vi ikke vet. Økt forståelse av demografiske, kliniske og biologiske forhold, og særlig om hvorledes slike faktorer gjensidig påvirker hverandre, vil forhåpentligvis resultere i både en bedre forståelse av suicidalitet ved affektive psykoser og i mer effektive intervensjoner.

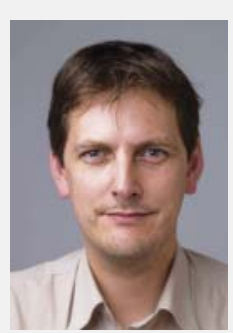

Erlend Mork er psykolog og stipendiat ved Oslo Univ.sykehus og NSSF (Nasjonalt senter for selvmordsforskning og -forebygging). Han forsker på selvmordsatferd blant pasienter med schizofreni og bipolar lidelse.

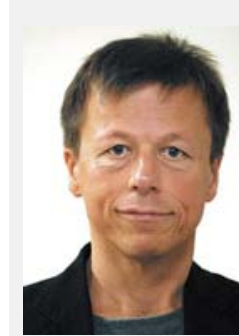

Lars Mehlum er psykiater og professor i suicidologi ved Univ. i Oslo. Han er leder for NSSF og er bredt engasjert i en rekke forsknings- og forebyggingspro sjekter. Han har publisert flere lærebøker samt en rek ke vitenskapelige artikler.

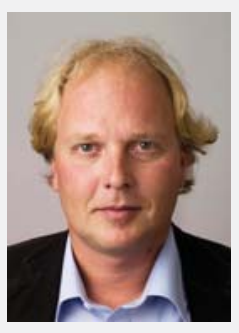

Fredrik A. Walby er sjefpsykolog ved Psykiatrisk avdeling, Diakonhjemmet sykehus og forsker ved NSSF Han har lang erfaring med forskning på kliniske grupper og med selvmordsforebygging blant psykotiske pasienter.

\section{Referanser}

Asberg, M., Träskman, L., Thorén, P. (1976). 5 HIAA in the cerebrospinal fluid: A biochemical suicide predictor. Archives of General Psychiatry, 33, 1193-1197.

Black, D. W., Monahan, P. O., Winokur, G. (2002). Suicidality and 5-hydroxyindoleacetic acid concentration associated with a tryptophane hydroxylase polymorphism. Annals of Clinical Psychiatry, 14, 83-88.

Black, D. W., Winokur, G., Nasrallah, A. (1988).

Effect of psychosis on suicide risk in 1,593 patients with unipolar and bipolar affective disorders. American Journal of Psychiatry, 145(7), 849-52.

Brent, D. A., \& Mann, J. J. (2005). Family genetic studies, suicide, and suicidal behavior. American Journal of Medical Genetics Part C-Seminars in Medical Genetics, $133 \mathrm{C}(1), 13-24$.

Carballo, J. J., Akamnonu, C. P., Oquendo, M. (2008). Neurobiology of suicidal behavior. An integration of biological and clinical findings. Archives of Suicide Research, 12, 93-110.

Caspi, A., Sugden, K., Moffitt, T., Taylor, A., Craig, I. W., Harrington, H., et al. (2003). Influence of life stress on depression: moderation by a polymorphism in the 5-HTT gene. Science, 301, 386-389.

Cavanagh, J.-T. O., Carson, A., Sharpe, M., Lawrie, S. (2003). Psychological autopsy studies of suicide: a systematic review. Psychological Medicine, 33(3), $395-405$. 


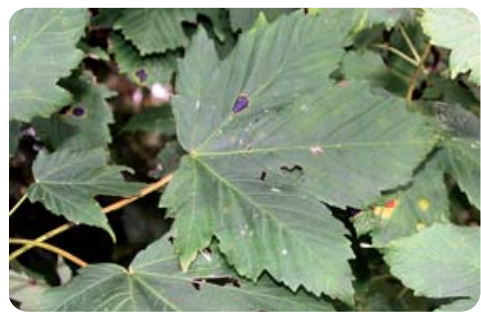

Courtet, P., Jollant, F., Castelnau, D., Buresi, C. Malafosse, A. (2005). Suicidal behavior: relationship between phenotype and serotonergic genotype. American Journal of Medical Genetics Part C - Seminars in Medical Genetics, 133(1), 25-33.

Ferrada-Noli, M., Asberg, M., Ormstad, K., Lundin, T., Sundbom, E. (1998). Suicidal behavior after severe trauma. Part 1: PTSD diagnoses, psychiatric comorbidity, and assessments of suicidal behavior. Journal of Traumatic Stress, 11(1), 103-112.

Fu, Q., Heath, A. C., Buchholz, K. K., Nelson, E. C., Glowinski, A. L., Goldberg, J., et al. (2002). A twin study of genetic and environmental influences on suicidality in men. Psycholocial Medicine, 32(11), 24 Glaser, D. (2000). Child abuse and neglect and the brain - a review. Journal of Child Psychology and psychiatry, 41(8), 1076

Goodwin, F. K., \& Jamison, K. R. (1990). Manicdepressiv illness. New York: Oxford University Press.

Harris, E. C. and Barraclough, B. (1997). Suicide as an outcome for mental disorders. A meta-analysis. The British Journal of Psychiatry, 170, 205-228.

Haw, C., Hawton, K., Sutton, L., Sinclair, J., Deeks, J. J. (2005). Schizophrenia and deliberate self-harm: a systematic review of risk factors. Suicide and LifeThreatening Behavior, 35, 50-62.

Hawton, K., Sutton, L., Haw, C., Sinclair, J., Harriss, L. (2005). Suicide and attempted suicide in bipolar disorder: a systematic review of risk factors. Journal of Clinical Psychiatry, 66(6), 693-704.

Inskip, H. M., Harris, E. C., Barraclough, B. (1998). Lifetime risk of suicide for affective disorder, alcoholism and schizophrenia. The British Journal of Psychiatry, 172, 35-37.

Isometsa, E. T., Henriksson, M. M., Aro, H. M., Lonnqvist, J. K. (1994). Suicide in bipolar disorder in Finland. American Journal of Psychiatry, 151(7), 1020-4.

Jamison, K. R. (2000). Suicide and bipolar disorder. Journal of Clinical Psychiatry, 61, Suppl 9, 47-51.

Keller, J., Schatzberg, A. F., Maj, M. (2007). Current Issues in the Classification of Psychotic Major Depression. Schizophrenia Bulletin, 33(4), 877-885.

Kessing, L. V. (2004). Severity of depressive episodes according to ICD-10: prediction of risk of relapse and suicide. The British Journal of Psychiatry, 184(2), 153-156

Kringlen, E., Torgersen, S., Cramer, V. (2001). A Norwegian Psychiatric Epidemiological Study. American Journal of Psychiatry, 158(7), 1091-1098

Leverich, G. S., Altshuler, L. L., Frye, M. A., Suppes, T., Keck, P. E., Jr., McElroy, S. L., et al. (2003). Factor associated with suicide attempts in 648 patients with bipolar disorder in the Stanley Foundation Bipolar Network. Journal of Clinical Psychiatry, 64(5), 506-15.

Leverich, G. S., McElroy, S. L., Suppes, T., Keck, P. E., Jr., Denicoff, K. D., Nolen, W. A., et al. (2002). Early physical and sexual abuse associated with an adverse course of bipolar illness. Biological Psychiatry, 51(4), 288-297.

Linnoila, M., Virkkunen, M., Scheinin, M., Nuutila, A., Rimon, R., Goodwin, F. K. (1983). Low cerebrospinal fluid 5-hydroxyindoleacetic acid concentrations differentiates impulsive from non-impulsive violent behavior. Life Sciences, 33(26), 2609-2614.
Lopez, J. F., Vazquez, D. M., Chalmers, D. T., Watson, S. J. (1997). Regulation of 5-HT receptors and the hypothalamic-pituitary-adrenal axis. Implications for the neurobiology of suicide. Annals of the New York Academy of Sciences, 836, 106-134.

Mann, J. J., \& Arango, V. (2001). Neurobiology of suicidal behavior. I D.Wasserman (red.), Suicide an unnecessary death. London: Dunitz.

Mann, J. J., \& Currier, D. (2007). Neurobiology of suicidal behavior. I R. Tatarelli, M. Pompili, \& P. Girardi (red.), Suicide in psychiatric disorders. New York: Nova Science Publishers.

Mann, J. J., Currier, D., Stanley, B., Oquendo, M. A., Amsel, L. V. Ellis, S. P. (2005) Can biological tests assist prediction of suicide in mood disorders? International Journal of Neuropsychopharmacology, 9(4) 465-74.

Mann, J. J., Oquendo, M., Underwood, M. L., Arango, V. (2003). Upregulation of the 5-HT2A receptor in prefrontal cortex is related to lifetime aggression. Biological Psychiatry, 53(8), 108S.

Mazza, J. J. and Reynolds, W. M. (1999). Exposure to violence in young inner-city adolescents: relationships with suicidal ideation, depression, and PTSD symptomatology. Journal of Abnormal Child Psychology, 27(3), 203-213.

Merikangas, K. R., Akiskal, H. S., Angst, J., Greenberg, P. E., Hirschfeld, R. M., Petukhova, M., Kessler, R. C. (2007). Lifetime and 12-month prevalence of bipolar spectrum disorder in the National Comorbidity Survey replication. Archives of General Psychiatry, 64(5), 543-52.

Nolan, K. A., Volavka, J., Czobor, P. (2000). Suicidal behavior in patients with schizophrenia is related to COMT polymorphism. Psychiatric Genetics 10 , $117-124$

Nordström, P., Samuelsson, M., Asberg, M., AbergWistedt, A., Nordin, C., Bertilsson, L. (1994). CSF 5-HIAA predicts suicide risk after attempted suicide. Suicide and Life-Threatening Behavior, 24, 1-9.

Palmer, B. A., Pankratz, V. S., Bostwick, J. M. (2005) The lifetime risk of suicide in schizophrenia: reexa-mination. Archives of General Psychiatry, 62 $247-253$

Pettersen, K., \& Rydningen, N. N. (2006). Autobiografisk hukommelse og selvmordsatferd hos pasienter med schizofreni. Hovedoppgave i Psykologi, Psykologisk Institutt, Universitetet i Oslo. Oslo.

Pini, S., de, Q., V, Pagnin, D., Pezawas, L., Angst, J., Cassano, G. B., Wittchen, H. U. (2005). Prevalence and burden of bipolar disorders in European countries. European Neuropsychopharmacology,15(4), 425-34.

Plotsky, P. M., Owens, M. J., Nemeroff, C. B. (1998) Psychoneuroendocrinology of depression. Hypothala-mic-pituitary-adrenal axis. Psychiatric Clinics of North America, 21(2), 293-307.

Qin, P. and Nordentoft, M. (2005). Suicide risk in relation to psychiatric hospitalization: evidence based on longitudinal registers. Archives of General Psychiatry, 62, 427-432.

Rao, M. L., Hawellek, B., Papassotiropoulos, A. Deister, A., Frahnert, C. (1998). Upregulation of the platelet Serotonin2A receptor and low blood serotonin in suicidal psychiatric patients. Neuropsychobiology, 38(2), 84-89.
Roose, S. P., Glassman, A. H., Walsh, B. T., Woodring S., Vital-Herne, J. (1983). Depression, delusions, and suicide. American Journal of Psychiatry, 140(9), 1159-1162.

Roy, A., Segal, N., Centerwall, D., Robinette, D. (1991). Suicide in twins. Archives of General Psychiatry, 48, 29-32.

Sanden, E. (2008). Autobiograpical Memory and Suicidal Behavior in Bipolar Disorder. Hovedoppgave i psykologi. Psykologisk institutt. Universitetet i Oslo. Oslo.

Sher, L., Carballo, J. J., Grunebaum, M. F., Burke, A K., Zalsman, G., Huang, Y. Y., et al. (2006). A prospective study of the association of cerebrospinal fluid monoamine metabolite levels with lethality of suicide attempts in patients with bipolar disorder. Bipolar Disorders, 8, 543-550.

Simon, G. E. and Von Korff, M. (1998). Suicide mortality among patients treated for depression in an insured population. American Journal of Epidemiology, 147(2), 155-160.

Simon, G. E., Hunkeler, E., Fireman, B., Lee, J. Y., Savarino, J. (2007). Risk of suicide attempt and suicide death in patients treated for bipolar disorder. Bipolar Disorders 9, 526-530.

Walby, F. A. (2004). Drap etterfulgt av selvdrap. Suicidologi, 9(1), 10-12.

Walby, F. A., Odegaard, E., Mehlum, L. (2006). Psychiatric comorbidity may not predict suicide during and after hospitalization. A nested casecontrol study with blinded raters. Journal of Affective Disorders, 92(2-3), 253-260.

Wender, P., Kety, S., Rosenthal, D., Schulzinger, F., Ortmann, J., Lunde, I. (1986). Psychiatric disorders in the biological and adoptive families of adopted individuals with affective disorders. Archives of General Psychiatry, 43, 923-929.

Wijkstra, J., Lijmer, J., Balk, F., Geddes, J., \& Nolen, W. (2005). Pharmacological treatment for psychotic depression. Cochrane Database of Systematic Reviews 2005 [On-line]. Hentet 31. august 2009 fra http://www.mrw.interscience.wiley.com/cochrane/ clsysrev/articles/CD004044/frame.html

Williams, J. M. G. (2001). Suicide and Attempted Suicide. (2. utg.) London: Penguin Books.

Wiste, A. K., Arango, V., Ellis, S. P., Mann, J. J., Underwood, M. D. (2008). Norepinephrine and serotonin imbalance in the locus coeruleus in bipolar disorder. Bipolar Disorders, 10(3), 349-359.

Ystgaard, M., Hestetun, I., Loeb, M., Mehlum, L. (2004). Is there a specific relationship between childhood sexual and physical abuse and repeated suicidal behavior? Child Abuse \& Neglect, 28(8), 863-875.

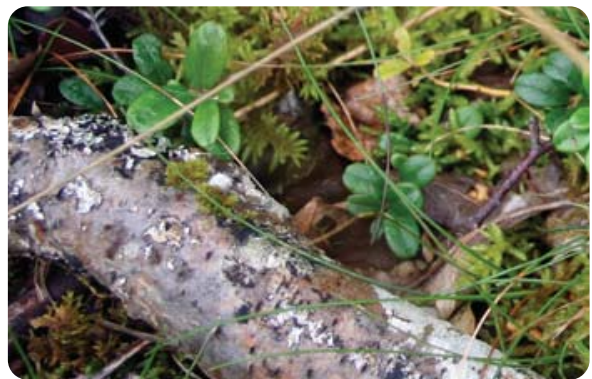

(Bilder: Ellen Jepson) 